\title{
PENGEMBANGAN SOSIOLINGUISTIK DALAM PENGAJARAN BAHASA ( SECARA TEORITIS DAN PENERAPAN) BAGI MAHASISWA PENDIDIKAN BAHASA
}

\author{
${ }^{1}$ Khairunnisa, ${ }^{2}$ Mustakim Sagita \\ ${ }^{1,2}$ Program Studi Pendidikan Bahasa Inggris \\ Fakultas Keguruan dan Ilmu Pendidikan Universitas Jabal Ghafur
}

\begin{abstract}
ABSTRAK
Sudah menjadi rahasia umum bahwa manusia adalah makhluk sosial yang tidak mungkin pernah mampu hidup tanpa terkait dengan unsur-unsur di sekitarnya, baik lingkungan manusia maupun alamnya. Dalam hidup bermasyarakat manusia tidak mungkin hidup sendiri tanpa interaksi dengan orang lain ataupun menolak kehadirannya. Secara naluriah manusia terdorong untuk menyatakan eksistensinya, mengekspresikan perasaannya, menyalurkan aspirasinya, memberikan pendapatnya maupun mempengaruhi orang lain demi kepentingan sendiri, kepentingan kelompok, maupun kepentingan bersama. Bahasa dan masyarakat tidak pernah bisa dipisahkan satu dengan yang lainnya, karena di mana ada masyarakat, di situ ada bahasa, dan sebaliknya. Dengan demikian bahasa menjadi salah satu syarat keberadaan suatu masyarakat tertentu. Keberadaan bahasa dalam masyarakat dipelajari melalui sosiolinguistik, yang memandang bahasa sebagai alat komunikasi antar anggota masyarakat dengan variasi-variasinya sesuai dengan ranah sosialnya. Di lain pihak, pengajaran bahasa tradisional memandang bahasa sebagai sistem, sehingga melahirkan pengajaran bahasa strukturalis. Dalam perkembangannya, para proponen metode pengajaran bahasa menyadari bahwa bahasa bukan sekedar sistem, namun lebih merupakan alat komunikasi, sebagaimana yang dipelajari melalui sosiolinguistik. Kajian ini membahas bagaimana peranan sosiolinguistik dalam perkembangan pengajaran bahasa, mulai dari karakteristik masyarakat bahasa, fungsi bahasa, sampai pada model- model pengajaran bahasa yang berbasis sosiolinguistik. Sosiolinguistik sendiri juga merupakan salah salah satu teknik pengajaran bahasa yang bertujuan sebagai manifestasi bahasa sosial dalam bidang linguistik pendidikan. Sosiolinguistik sebagai bagian dari linguistik makro tidak hanya membahas aspek-aspek yang sempit, namun juga berbagai aspek yang luas, seperti variasi bahasa interferensi sebagai bentuk penyimpangan bahasa, dan etnografi komunikasi sebagai wujud masyarakat yang beraneka budaya. Bahan di dalam pengajaran bahasa juga ditentukan oleh sosiolinguistik. Tulisan ini akan mengulas mengenai kontribusi sosiolinguistik dalam penyediaan bahan pengajaran bahasa dari sudut pandang sosiolinguistik dan penentuan variasi bahasa (termasuk pronomina persona) yang digunakan di perguruan tinggi khususnya mahasiswa bahasa baik bahasa indonesia maupun bahasa inggris, penentuan interferensi yang muncul pada komunikasi pembelajar sebagai suatu bentuk kesalahan bahasa, etnografi komunikasi dalam pengajaran bahasa Indonesia untuk pengguna bahasa asing (BIPA), dan Bahasa Inggris sebagai entitas bahasa Asing. Tahapan penelitian ini ditujukan pada mahasiswa semester VI yang sedang mengambil mata kuliah sosiolinguistik yang bertujuan sebagai media perbandingan untuk mengukur analisa mahasiswa dalam memahami dan menerapkan sosiolinguistik baik dilingkungan mikro yaitu kelas, sampai dengan lingkungan makro yaitu masyarakat.

Dengan target luaran yang ingin dicapai yaitu jurnal nasional ber ISSN dan buku ajar untuk mata kuliah sosiolinguistik. Untuk level TKT berada pada level 5 yaitu sosial humaniora.

Kata kunci: Sosiolinguistik, pengajaran bahasa, variasi bahasa, interferensi, etnografi komunikasi, dan bahan pengajaran bahasa.
\end{abstract}

\section{Latar Belakang}

Sebagai objek dari sosiolinguistik, bahasa tidak dilihat atau didekati sebagai bahasa, sebagaimana dilakukan oleh linguistik umum, melainkan dilihat atau didekati sebagai sarana interaksi atau komunikasi di dalam masyarakat manusia (Chaer dan Agustina,2010:3). Bahasa sebagai sarana komunikasi di dalam masyarakat lebih menitik beratkan pada 
penggunanan bahasa yang bertujuan membuat komunikasi antara penutur dan mitra tutur berjalan dengan baik walaupun dilakukan secara kedwibahasaan. Jika dikaji lebih mendalam, maka komponenkomponen dari masyarakat di antaranya adalah adanya sekumpulan orang, yang menduduki suatu areal tertentu, memiliki kultur yang sama, menjunjung nilai-nilai dan norma- norma yang sama, serta saling berinteraksi (Holmes, 2001). Interaksi yang dilakukan antara anggota masyarakat dengan menggunakan bahasa, sehingga jelaslah bahwa bahasa merupakan bagian dari mayarakat. Bahkan tidak bisa dibayangkan jika suatu masyarakat tidak memiliki bahasa, maka namanya bukan masyarakat.

Interaksi merupakan sifat dasar yang dimiliki oleh setiap manusia di dalam masyarakatnya, dan bahasa menjadi satu sarana terpenting untuk terjadinya sebuah interaksi tersebut (Soebroto, 2007). Namun kita semua juga mengerti bahwa tidak semua orang di seluruh dunia menggunakan satu bahasa yang sama. Agar proses interaksi di antara masyarakat yang memiliki bahasa yang berbeda tetap berjalan dengan baik, maka di antara mereka perlu sebuah pemahaman atau kesepakatan mengenai makna dalam bahasa yang mereka gunakan (Hymes dan Agustina, 2010). Hal inilah yang menjadikan dasar perlunya sebuah pengajaran dan atau pembelajaran bahasa di dalam masyarakat. Komunikasi antar anggota masyarakat, terutama yang memliki perbedaan bahasa, akan menjadi lancar ketika di dalam masyarakat tersebut telah terjadi proses pembelajaran bahasa, yang dilakukan secara formal maupun informal.

Berdasarkan dasar pemikiran sebagaimana diuraikan di atas, pengajaran bahasa menjadi salah satu bidang terpenting yang dibahas dalam perkembangan ilmu pengetahuan, utamanya bidang pengajaran. Tidak heran bahwa teori-teori yang berkaitan dengan bahasa dan pengajaran bahasa juga berkembang sejalan dengan perkembangan peradaban manusia. Perkembangan teori bahasa dan pengajaran bahasa tersebut memiliki sejarah tersendiri di dalam khasanah ilmu yang berkembang di dunia (Richards, 2001). Hal itu bisa dikaji melalui perubahan-perubahan yang terjadi dalam teori yang berkaitan dengan pengajaran bahasa. Kemajuan demi kemajuan yang dicapai oleh teori bahasa memiliki dampak yang secara langsung maupun tidak langsung terhadap teori pengajaran bahasa, bahkan bisa dikatakan bahwa teori bahasa tersebut menjadi dasar filosofis dari teori pengajaran bahasa. Dengan demikian teori bahasa yang berkembang pada suatu era tertentu akan tercermin atau mempengaruhi teori pembelajaran bahasa pada era tersebut (Oliva \& Fathur Rokhman 2013). Misalnya, perkembangan teori linguistik struktural pada tahun 1920-an sampai dengan tahun 1970-an berpengaruh sangat kuat terhadap teori pengajaran bahasa seperti: Metode Audiolingual dan Grammar Translation Method.

Teori linguistik struktural tersebut melihat bahwa bahasa merupakan suatu struktur kata-kata yang memiliki keberaturan, dan mempelajari bahasa artinya mempelajari struktur bahasa tersebut (Richards, 2001). Perkembangan teori linguistik berikutnya, pada tahun 1970-an sampai sekarang, yang dimulai oleh Chomsky, yang mengatakan bahwa bahasa tidak sekedar struktur korpus sebagaimana dikemukakan oleh para strukturalis, namun lebih merupakan struktur batin yang mendasari kemampuan berbahasa secara keseluruhan (Aitchison, 2004). Kemudian teori sosiolinguistik Hymes menyempurnakan dasar-dasar teori Chomsky mengenai kemampuan berbahasa melalui konsep communicative competence.

(Hymes dalam Fathur Rokhman 2013) menyatakan bahwa kompetensi bahasa seseorang ditandai dengan pengetahuan yang menyeluruh mengenai sistem bahasa yang dimaksud, termasuk penggunaannya dalam komunikasi riil. Konsep communicative competence yang disampaikan oleh Hymes tersebut memengaruhi perkembangan teori pengajaran bahasa sampai sekarang, dengan munculnya metode-metode pengajaran bahasa seperti: Communicative approach dan competency-based language teaching. 


\section{Tinjauan Pustaka}

Prinsip-prinsip Dasar Sosiolinguistik

Hubungan Bahasa dengan Masyarakat

Salah satu sifat alami bahasa adalah bahwa bahasa itu arbitrer, yang diciptakan sewenang-wenang oleh masyarakat bahasa tersebut (Soebroto, 2007), artinya bahwa tidak ada hubungan (langsung) antara bentuk bahasa dengan makna yang dimasud dalam bahasa itu. Dengan sifatnya yang arbitrer, maka kita tidak akan bisa mengetahui alasannya mengapa suatu bentuk kata (bahasa) digunakan untuk mengacu pada suatu makna tertentu pada suatu bahasa tertentu (Francis, 2002). Sehingga bahasa diciptakan bebas oleh masyarakat pemakainya. Satu- satunya pembatas dari sifat arbitrer bahasa itu adalah konvensi sosial. Artinya, bahwa proses penciptaan bahasa tidak terikat oleh sesuatu apa pun kecuali konvensi sosial.

\section{Bahasa sebagai Perilaku Sosial}

Labov, et Trudgil (2004) menyatakan bahwa bahasa adalah perilaku sosial, bahasa bukan saja susunan kata-kata, namun dibalik susunan kata-kata itu terdapat nilainilai sosial yang dijunjung tinggi oleh masyarakat bahasa itu. Orang, sebagai anggota sebuah masyarakat, akan selalu terikat dengan nilai-nilai tersebut ketika menggunakan bahasa itu. Seseorang tidak akan pernah meninggalkan nilai- nilai sosial tersebut dalam menggunakan bahasanya atau akan memiliki risiko dianggap tidak sopan.

\section{Domain Sosial dan Variasi Bahasa}

Domain sosial adalah keseluruhan konstruk masyarakat di mana suatu bahasa digunakan (Fishman, dalam Fathur Rokhman 2013). Domain sosial meliputi konteks sosial (speech events) seperti setting, peserta tutur, topik pembicaraan, hubungan peran, okupasi, dan situasi (Hymes, dalam Fathur Rokhman 2013). Domain sosial tersebut akan berpengaruh sangat besar terhadap bahasa yang dipakai oleh pemakai bahasa itu. Kecuali rasa bahasa yang diakibatkan oleh perbedaan domain, ada hal yang lebih penting yaitu variasi bahasa.
Sebagai alat komunikasi, bahasa memiliki berbagai fungsi, di antaranya alat untuk tukar-menukar informasi, alat untuk mengekspresikan ide, alat untuk mempertahankan nilai kebanggaan kelompok, dan sebagainya, bahkan sampai pada fungsi untuk mempertahankan hubungan sosial (Robinson, dalam Fathur Rokhman 2013). Dalam beberapa hal, pemakai bahasa lebih terikat kepada fungsi bahasa daripada kepada bentuk bahasa, di mana makna bahasa seringkali tidak konsisten dengan bentuk yang dipilihnya.

\section{Konsep-konsep Sosiolinguistik dalam Pengajaran Bahasa \\ Competency-based Language Teaching}

Diawali pada tahun 1970-an, pembelajaran bahasa didasarkan pada kemampuan berbahasa yang beorientasi pada pekerjaan dan pertahanan hidup yang diperuntukkan bagi pembelajar dewasa (Richards, 2001: 141). CBLT medasarkan filosofinya pada perspektif fungsional dan interaksional bahasa secara alami. Metode pembelajaran bahasa ini disusun berdasarkan communicative competence dan berusaha untuk mengembangkan kemampuan berbahasa secara fungsional. Dalam banyak hal CBLT memiliki kesamaan ciri dengan communicative language teaching.

\section{Communicative Language Teaching}

Sebagai tanggapan terhadap Chomsky (2012) yang menyebutkan adanya "kreativitas" dalam penggunaan bahasa oleh pemakainya, maka banyak pendapat yang muncul bahwa metode-metode pengajaran bahasa yang menggunakan teori linguistik struktural sebagai landasan filosofisnya tidak lagi layak untuk diteruskan. Diawali dengan teori Hymes (2013) mengenai communicative competence, bahasa dilihat sebagai alat komunikasi, sehingga kemampuan berbahasa dilihat dari kemampuan seseorang untuk menggunakannya dalam komunikasi.

\begin{tabular}{lrr}
\multicolumn{1}{c}{ Menurut } & Hymes & kompetensi \\
komunikatif & meliputi & keseluruhan \\
pemahaman tentang sistem bahasa, beserta
\end{tabular}


penerapannya dalam komunikasi riil (Richards, 2001:159). Sedangkan menurut Chomsky, competence diartikan sebagai struktur batin yang mendasari komunikasi dengan menggunakan kalimat yang tak terhitung jumlahnya (Aitchison, dalam Fathur Rokhman 2013). Dalam penerapannya, pendapat Hymes digunakan sebagai landasan filosofis dari Communicative Language Teaching. Communicative Language Teaching menekankan pembelajaran bahasa dari dimensi komunikasi.

\section{Natural Approach}

Prinsip dasar dari natural approach sama dengan communicative approach, yaitu melihat bahasa sebagai alat komunikasi yang wajar. Dalam penerapannya sebagai metode pembelajaran, natural approach menekankan prinsip naturalistik yang lebih banyak mengedepankan keterlibatan (exposure) dalam bahasa target. Keterlibatan secara langsung dalam pemakaian bahasa target secara natural akan memungkinkan terjadinya pemerolehan bahasa (language acquisition) (Richards, 2001:179). Prinsip dari natural approach adalah pengembangan kompetensi bahasa target dengan proses "akuisisi" bahasa secara natural.

\section{Cooperative Language Learning}

Born to Talk merupakan landasan pembelajaran bahasa dalam cooperative language learning (Weeks, 2009). Bahasa sebagai objek pembelajaran dilihat sebagai alat untuk melakukan interaksi sosial di dalam masyarakat. Dalam kehidupan seharihari manusia banyak dilibatkan dalam percakapan (penggunaan bahasa) dalam kerangka interaksi sosial. Sedangkan percakapan di antara anggota masuarakat terikat oleh sebuah tatanan (aturan/nilai) yang disepakati di antara mereka (Richards, 2001: 193). Grammar (bentuk bahasa) akan banyak bergantung dari nilai-nilai suatu masyarakat pada suatu saat tertentu dan pada tempat tertentu.

\section{Pembelajaran Bahasa di Sekolah}

Perubahan

metode-metode pembelajaran sebagaimana dijelaskan di atas terjadi secara internasional. Di Indonesia sendiri, perubahan seperti tersebut di atas juga terjadi. Perubahan tersebut tercermin di dalam kurikulum yang diberlakukan secara nasional di Indonesia. Kurikulum 1994 mengadopsi nama Communicative Approach, khusus untuk pembelajaran bahasa yang mendasarkan pada teori sosiolinguistik sebagaimana dijelaskan pada subbab sebelumnya. Perkembangan kurikulum selanjutnya ialah Kurikulum 2004 atau Kurikulum Berbasis Komptensi dan Kurikululum K-13 dan Kurikulum Tingkat Satuan Pendidikan (KTSP). Dilihat dari nama kurikulum tersebut sudah memperlihatkan adanya pengaruh dari teori sosiolinguistik di dalam kurikulum pengajaran (bahasa) di Indonesia.

\section{Bahasa Sebagai Alat Komunikasi}

Salah satu konsep sosiolinguistik yang menonjol adalah bahwa bahasa, yang dalam hal ini digunakan sebagai objek belajar, dilihat sebagai alat untuk berkomunikasi. Pada kurikulum pengajaran bahasa sebelumnya (Kurikulum 1994) bahasa dilihat sebagai sekumpulan aturan (sistem), sehingga mempelajari bahasa dilakukan dengan mempelajari struktur-struktur yang ada di dalam bahasa target itu, mulai dari tata bunyi, tata kata, dan tata kalimat. Hasil belajar bahasa pada masa-masa tersebut adalah kemampuan untuk menggunakan tata bahasa yang baik dan benar dilihat dari sisi tata bahasanya. Namun cara belajar dengan pendekatan structural semacam ini dinilai seringkali mengalami kegagalan dalam komunikasi riil, di mana bahasa akan bervariasi berdasarkan pada domain sosial atau speech even yang belaku pada saat itu. Tata bahasa yang benar belum tentu komunikatif.

\section{Ketrampilan Berbahasa Bersifat Menyeluruh}

Prinsip pembelajaran bahasa yang menyeluruh ini diilhami oleh konsep 
sosiolinguistik communicative competence yang dinyatakan oleh Hymes. Sebagai perbaikan dari konsep Chomsky, yang dimaksud dengan communicative competence oleh Hymes adalah untuk mampu berbahasa dengan baik, seseornag harus memiliki pemahaman tentang seluruh sistem bahasa itu serta penerapannya dalam konteks-konteks tertentu pula. Jadi orang dikatakan memiliki kompetensi bahasa tertentu jika ia mengerti aturan kebahasaan dari bahasa tersebut dan mampu menggunakannya dalam konteks yang dimaksud. Implikasi dari prinsip kompetensi bahasa ini tercermin dalam strategi pembelajaran sebagaimana dijelaskan berikut ini.

Pertama, strategi belajar tuntas (Mulyasa, 2004:27) yang memiliki pengertian bahwa dalam kondisi yang tertentu, setiap pembelajar akan mampu menguasai materi instruksional dengan baik. Hal yang membuat perbedaan antara pembelajar yang satu dengan yang lainnya hanyalah terletak pada faktor waktu. Bagi yang berbakat (talented) membutuhkan waktu penguasaan materi lebih pendek dibandingkan dengan pembelajar yang kurang berbakat. Dan jika masing- masing dari mereka diperlakukan sesuai dengan kondisinya masing-masing maka akan tercapai tujuan instruksional oleh semua pembelajar. Strategi pembelajaran ini memperhatikan pluralitas pembelajar dengan memberikan perlakuan yang berbeda, sehingga menjadi lebih human.

Kedua, tujuan instruksional disusun atas dasar kebutuhan akan ketrampilan bahasa yang dimiliki oleh siswa. Sebelum guru merumuskan tujuan instruksional, ia akan terlebih dahulu mengkaji ketrampilan bahasa seperti apa yang harus disajikan dalam pembelajaran (Mulyasa, 2004:72). Strategi ini akan memberikan kemanfaatan secara langsung mengenai ketrampilan berbahasa siswa yang diperoleh di dalam kelas.

Ketiga, berkaitan dengan butir kedua di atas, tujuan instruksional berorientasi pada hasil belajar. Diharapkan bahwa grammar yang didapatkan siswa sesuai dengan penggunaan bahasa secara riil. Karena tugastugas instruksional selalu mengacu pada fungsi bahasa dalam konteks nyata, maka hasil belajar bisa diterapkan secara langsung dalam masyarakat bahasa.

Keempat, pendekatan pembelajaran yang digunakan berupa natural approach, di mana proses pembelajaran dilakukan dengan strategi yang paling denkat dengan kenyataan pemakaiab bahasa secara alamidan wajar. Dalam hal ini, tentunya materi instruksional bersifat autentik sebagaimana dijelaskan terdahulu. Bagaimana masyarakat mengunakan bahasa itu secara wajar, maka seperti itulah materi instruksional disusun.

\section{METODE PENELITIAN}

Pendekatan Penelitian

Pendekatan yang digunakan dalam penelitian ini menggunakan pendekatan penelitian kualitatif dengan metode deskriptif. Pendekatan tersebut digunakan mengingat beberapa hal yang menjadi ciri penelitian kualitatif. Menurut Moleong (2006 : 8 - 13) yang menyebutkan beberapa ciri yang ada dalam proses pelaksanaannya, yaitu berakar pada latar alamiah atau pada konteks dari suatu keutuhan, mengandalkan manusia sebagai alat penelitian, menggunakan metode kualitatif, menganalisis data secara induktif, mengarahkan sasaran penelitiannya pada usaha menemukan teori dari dasar, bersifat deskriptif, lebih mementingkan proses daripada hasil, membatasi studi dengan fokus, memiliki seperangkat kriteria untuk memeriksa keabsahan data, rancangan penelitiannya bersifat sementara, dan hasil penelitiannya disepakati oleh kedua belah pihak, yaitu peneliti dan subjek penelitian.

Alasan peneliti menggunakan pendekatan kualitatif deskriptif, karena permasalahan yang dibahas dalam penelitian ini tidak berhubungan dengan angka- angka, akan tetapi menyangkut pendeskripsian, penguraian dan penggambaran suatu masalah yang sedang terjadi. Penelitian 
deskriptif ini bertujuan agar peneliti dapat mendeskripsikan secara jelas dan terperinci tentang Sosiolinguistik dalam pembelajaran bahasa serta memperoleh data dari permasalahan penelitian yaitu. Bagaimanakah upaya Pengembangan sosiolinguistik dalam meningkatkan minat berbicara bahasa kedua mahasiswa dan bagaimanakah hasil dari upaya yang dilakukan Pembimbing mata kuliah sosiolinguistik dalam meningkatkan ketertarikan berbahasa.

\section{Lokasi Penelitian}

Penelitian ini dilaksanakan Mahasiswa Bahasa Inggris Semester VI yang ditentukan secara purposive (menurut tujuan penelitian). Menurut Moleong (2006 : 88) sebelum mulai menentukan tempat penelitian terlebih dahulu peneliti harus mengadakan penjajakan dan penilaian lapangan. Penjajakan ini akan terlaksana dengan baik apabila sebelumnya peneliti sudah mempunyai gambaran umum mengenai keadaan dan semua yang relevan dengan sasaran penelitian.

Ditentukannya lokasi penelitian tersebut dengan alasan-alasan sebagai berikut:

1. Mata Kuliah Sosiolinguistik di ajarkan untuk semester VI Program Studi Bahasa Inggris yang berupaya membimbing mahasiswa mempelajari sosiolinguistik.

2. Mahasiswa semester VI Program Studi Bahasa Inggris memenuhi unsur pelaksanaan penelitian, hal ini mencakup jumlah ideal mahasiswa dikelas tersebut.

\section{Subjek Penelitian}

Dalam upaya menjaring informasi yang sesuai dengan kebutuhan penelitian, maka dilakukan pemilihan informan. Pemilihan informan didasarkan pada beberapa pertimbangan antara lain: informan tersebut memahami tentang permasalahan dan mampu memberikan penjelasan yang diperlukan peneliti sesuai dengan fungsi informan tersebut. Selain itu informan tersebut juga terlibat secara langsung maupun tidak langsung dalam setiap perkuliahan sebelumnya.

Subjek penelitian yang dipilih dalam penelitian ini adalah dosen dan mahasiswa yang mengajar mata kuliah sosiolinguistik, dengan responden mahasiswa berjumlah 25 orang. Dosen yang dijadikan responden yaitu 2 orang dengan kriteria : sudah berpengalaman sebagai dan memahami permasalahan dalam pembelajaran mata kuliah Sosiolinguistik. Untuk mendukung data yang diperoleh, wawancara juga dilakukan terhadap Ketua Prodi Pendidikan Bahasa Inggris dengan pertimbangan dia lebih memahami hal-hal yang berkaitan dengan Program Studi Secara keseluruhan.

\section{Teknik Pengumpulan Data}

Menurut Lexy J. Moleong (Moleong, 2006 : 125-163) metode yang sering digunakan dalam penelitian kualitatif yaitu pengamatan, wawancara, catatan lapangan dan penggunaan dokumen. Namun demikian penggunaannya harus disesuaikan harus disesuaikan dengan penelitian yang sedang dilakukan sehingga ada kecocokan. Dalam penelitian ini, metode pengumpulan data yang digunakan adalah:

1. Wawancara

Wawancara digunakan sebagai teknik pengumpulan data apabila peneliti ingin melakukan studi pendahuluan untuk menemukan permasalahan yang harus diteliti, tetapi juga apabila peneliti ingin mengetahui hal-hal dari responden yang lebih mendalam (Sugiyono, 2009 : 231)

2. Observasi

Observasi adalah pengamatan dan pencatatan dengan sistematik fenomenafenomena yang diteliti. Nasution dalam Sugiyono (2009 : 226) menyatakan bahwa observasi adalah dasar semua ilmu pengetahuan. Para ilmuwan hanya dapat bekerja berdasarkan data, yaitu fakta mengenai dunia kenyataan yang diperoleh melalui observasi. Marshall dalam Sugiyono (2009: 226) menyatakan bahwa melalui observasi, peneliti belajar tentang perilaku dan makna perilaku tersebut. Hal-hal yang diobservasi adalah hal yang berkaitan dengan 
upaya Program Studi Pendidikan Bahasa Inggris dalam meningkatkan minat berbicara bahasa Inggris mahasiswa.

3. Dokumentasi

Teknik pengumpulan data melalui dokumentasi ini dimaksudkan untuk melengkapi data hasil wawancara dan observasi. Dokumentasi diperoleh dari data yang ada Metode pengumpulan data melalui dokumentasi digunakan untuk memperoleh data dan informasi resmi yang terkait dengan pengelolaan serta upaya Pembelajaran Sosiolinguistik.

\section{Tahap Penelitian}

Tahapan-tahapan penelitian yang dilaksanakan dalam penelitian ini yaitu :

1. Tahap orientasi, meliputi survey awal lembaga dan studi kepustakaan. Pada tahap ini peneliti terjun ke lokasi penelitian dan melakukan wawancara dengan pihak-pihak yang berkompeten serta mengutarakan maksud dan tujuan kedatangan peneliti. Peneliti juga melakukan observasi awal untuk menentukan kelayakan subjek penelitian. Selanjutnya peneliti mengumpulkan referensi-referensi yang berhubungan dengan topik penelitian dan selanjutnya disusun sebagai proposal penelitian.

2. Tahap eksplorasi. Tahap ini merupakan tahap pengumpulan data yang dilakukan dengan cara wawancara yang mendalam, observasi partisipan, dan studi dokumentasi.

3. Tahap pengecekan keabsahan data. Pengecekan keabsahan data dalam penelitian dilakukan agar dapat dihasilkan temuan dan interpretasi data yang absah dan dapat diterima semua pihak. Pengecekan keabsahan data dilakukan setiap saat setelah peneliti terjun ke lapangan dan mengumpulkan data.

4. Tahap penganalisisan data. Pada tahap ini kegiatan yang dilakukan yaitu : reduksi data, display data dan penarikan kesimpulan. Penganalisisan data dilakukan dilakukan setelah semua data terkumpul.
5. Tahap penulisan laporan penelitian. Pada tahap ini, semua temuan-temuan penelitian dituliskan secara sistematis dan bermakna.

\section{Teknik Penganalisisan Data}

Analisis data kualitatif adalah upaya yang dilakukan dengan jalan bekerja dengan data, mengorganisasikan data, memilahmilahnya menjadi satuan yang dapat dikelola, menemukan apa yang penting dan apa yang dipelajari, dan memutuskan apa yang dapat diceritakan kepada orang lain (Bogdan dan Biklen dalam Moleong, 2006 : 248).

Selanjutnya menurut Janice Mc Drury (Moleong, 2006 : 248) tahapan analisis data kualitatif adalah sebagai berikut: 1) Membaca atau mempelajari data, menandai kata-kata kunci dan gagasan yang ada dalam data; 2) Mempelajari kata-kata kunci itu, berupaya menemukan tema-tema yang berasal dari data; 3) Menuliskan "model" yang ditemukan; 4) Koding yang telah dilakukan.

Teknik penanalisisan data yang digunakan dalam penelitian ini meliputi : (1) Reduksi Data; (2) Display Data dan ; (3) Penarikan Kesimpulan. Berikut ini penjelasan secara rinci mengenai teknik penganalisisan data yang digunakan.

\section{Keabsahan Data}

Pengecekan keabsahan data dalam penelitian dilakukan agar dapat dihasilkan temuan dan interpretasi data yang absah dan dapat diterima semua pihak. Oleh karena itu diperlukan kredibilitas melalui berbagai instrumen : luangan waktu sebaik mungkin peneliti di lapangan, observasi yang intensif, triangulasi (menggunakan beberapa metode, sumber, peneliti, dan teori), pembahasan teman sejawat. Selanjutnya perlu dilakukan pengecekan dapat tidaknya ditransfer ke latar lain (transferability), pada konteksnya (dependability), dan dapat tidaknya dikonfirmasikan kepada sumbernya (confirmability) (Moleong dalam Harsono, 2008 : 172). 
Teknik yang digunakan untuk pengecekan keabsahan data dalam penelitian antara lain efektivitas penggunaan waktu. Pemakaian waktu peneliti di lapangan diusahakan berjalan secara efektif, hal ini sangat penting khususnya untuk menghindarkan diri dari kegiatan yang siasia, misalnya terjebak pada pembicaraan yang tidak sesuai dengan fokus. Semua kegiatan yang dilakukan di lapangan tidak lain adalah untuk mencari data, baik data awal, data berjalan, ataupun informasi yang bersifat rechecking. Dengan demikian peneliti menerapkan prinsip fleksibel, karena mungkin ada kegiatan inti pengumpulan data dan ada kegiatan penunjang dalam rangka penggalian data. Peneliti mempersiapkan terlebih dahulu pedoman untuk menggali data di lapangan, antara lain pedoman wawancara, pedoman observasi dan pedoman studi dokumentasi. Selanjutnya peneliti terjun ke lokasi penelitian dan menyampaikan maksud tujuan kehadirannya. Setelah itu proses penggalian data dilakukan sesuai dengan pedoman. Dalam melakukan wawancara terhadap subjek kadang-kadang pembicaraan keluar dari fokus, maka peneliti segera mengembalikan pembicaraan pada fokusnya. Atau jika penjelasan yang disampikan subjek kadang-kadang kurang lengkap, maka peneliti terus mengejar dengan pertanyaan sampai informasi yang didapat lengkap.

Teknik berikutnya yang dipakai peneliti yaitu dengan observasi intensif. Teknik ini dipakai supaya diperoleh informasi yang tajam, dalam, dan akurat hingga sampai pada akar informasi. Informasi yang diharapkan diperoleh berkaitan dengan pengalaman, perasaan, penglihatan, pemikiran informan yang sesuai dengan topik khusus yang dikaji. Peneliti menjalin kedekatan emosional dengan peserta didik dengan cara berbaur mengikuti aktifitas mereka.

Teknik selanjutnya yaitu dengan cara triangulasi. Triangulasi diartikan sebagai pengecekan data dari berbagai sumber dengan berbagai cara dan berbagai waktu (Wiliam Wiersma dalam Sugiyono, 2009 :
273). Dengan demikian terdapat triangulasi sumber, triangulasi teknik pengumpulan data, dan waktu.

Dalam penelitian ini triangulasi dilakukan dengan jalan membandingkan dan mengecek informasi atau data yang diperoleh dari wawancara dengan hasil pengamatan, dengan teori yang ada dan mencocokkan dengan nara sumber. Teknik berikutnya yang digunakan peneliti yaitu pengecekan anggota Menurut Moleong (2006 : 335) pengecekan dengan anggota yang terlibat dalam proses pemgumpulan data sangat penting dalam pemeriksaan derajat kepercayaan. Selanjutnya dijelaskan bahwa data yang dicek dengan anggota yang terlibat meliputi data, kategori analisis, penafsiran, dan kesimpulan (Moleong, 2006:335).

Pengecekan anggota (member check) berarti memperbanyak atau memperlihatkan sajian dan olahan data kepada informan yang bersangkutan untuk diperiksa kebenarannya. Dalam penelitian ini pengecekan anggota dilakukan dengan cara memperlihatkan data yang sudah diolah dari hasil wawancara, observasi maupun dokumentasi kepada penyelenggara,tutor maupun peserta didik. Mereka diminta untuk memeriksa kebenaran data yang sudah di peroleh tersebut. Dari hasil pengecekan anggota ini,maka data yang akan disajikan dapat dipertanggung jawabkan keabsahannya.

\section{DAFTAR RUJUKAN}

Chaer, Abdul dan Leonie Agustina. 2010. Sosiolinguistik Perkenalan Awal. Jakarta: Rineka Cipta.

Holmes, J. 2001. An Introduction to Sociolinguistics. England: Pearson EducationLimited.

Soebroto, S. 2007. Temuan Linguistik untuk Pengajaran Bahasa. Surakarta: Universitas Negeri Sebelas Maret. 
Richards, J. C. and Rodgers, T. 2001. Approaches and Methods in Language

Teaching. Cambridge: Cambridge University Press.

Fathur Rokhman, 2013. SOSIOLINGUISTIK, Suatu Pendekatan Pembelajaran Bahasa dalam Masyarakat Multikultural. Yogyakarta : Graha Ilmu

Spolsky, Bernard. dan Francais M. Hult. (2008). The Hanbook Of Educational Linguistics.

Spolsky, Bernard. 2010. Sosiolinguistics. New York: Oxford University Press.

Joyce, B., dan Weil, M. 2000. Models of Teaching. London: Allyn and Bacon.

Mulyasa, E. 2004. Kurikulum Berbasis Kompetensi: Konsep, Karakteristik dan Implikasi. Bandung: PT Remaja Rosdakarya.

Nurhadi. 2004. Kurikulum 2004. Jakarta: PT Gramedia Widiasarana Indonesia.
Richards, J. C. 2001. Curriculum and Material Developmen for English Teaching. Cambridge: Cambridge University Press.

Richards, J.C.(2002). Curriculum Development in Language Teaching. Cambridge: Cambridge University Press.

Undang-Undang Republik Indonesia Nomor 20 Tahun 2003 tentang Sistem Pendidikan Nasional

Alwi, Hasan. Dkk. 2003. Tata Bahasa Baku Bahasa Indonesia Edisi Ketiga Jakarta: Balai Pustaka.

Brown. Douglas. 2007: Prinsip Pembelajaran Dan Pengajaran Bahasa Edisi Kelima. Jakarta.

Sugiyono. 2006. Metode Penelitian Kualitatif, Kuantitatif, R\&D. Bandung: Alfabeta.

Moleong, Lexy J. 2010. Metode Penelitian Kualitatif. Bandung: Remaja. 